Canadian University Music Review

Revue de musique des universités canadiennes

\title{
Towards a Feminist Criticism of Music
}

\section{Susan McClary}

Volume 10, numéro 2, 1990

Alternative Musicologies

Les Musicologies Alternatives

URI : https://id.erudit.org/iderudit/1014882ar

DOI : https://doi.org/10.7202/1014882ar

Aller au sommaire du numéro

Éditeur(s)

Canadian University Music Society / Société de musique des universités canadiennes

ISSN

0710-0353 (imprimé)

2291-2436 (numérique)

Découvrir la revue

Citer cet article

McClary, S. (1990). Towards a Feminist Criticism of Music. Canadian University Music Review / Revue de musique des universités canadiennes, 10(2), 9-18.

https://doi.org/10.7202/1014882ar

All Rights Reserved @ Canadian University Music Society / Société de musique des universités canadiennes, 1990
Ce document est protégé par la loi sur le droit d'auteur. L'utilisation des services d'Érudit (y compris la reproduction) est assujettie à sa politique d'utilisation que vous pouvez consulter en ligne.

https://apropos.erudit.org/fr/usagers/politique-dutilisation/ 


\title{
TOWARDS A FEMINIST CRITICISM OF MUSIC
}

\author{
Susan McClary
}

At a time when both male and female scholars in most branches of the humanities practice some form of feminist-influenced criticism, the discipline of musicology remains relatively untouched by feminism. To be sure, there has been considerable work accomplished within the last decade towards rediscovering the contributions of women to the history of music, and the place of women within today's musical institutions has also come under scrutiny. But a critique of music from a feminist perspective has scarcely begun.

It is important to keep in mind that music traditionally has resisted not only feminist criticism but all forms of socially grounded criticism. Because of its relatively abstract modes of construction, music has long been held to be impervious to interpretations that would link its patterns to concerns of the material or social world: concerns such as gender and sexuality, but also race, ethnicity, and class. Part of the rationale for this resistance was articulated to me recently by a well-meaning, liberal musicologist who asked: "How is the work of art to survive the social critique? Is there a remedy that does not violate the work?"

Recent statements by scholars such as Joseph Kerman make it seem that on the one hand musicology is eager to have instances of feminist criticism; but, on the other hand, the discipline is apprehensive about how far the critique would go and about the consequences with respect to the canon. The ideal form of feminist critique would appear to be one that contributed new insights but that did not challenge received conceptions and judgments. The great composers and traditional notions of what makes them great would remain securely in place, but we would have yet another reason to pay them homage: the sympathetic portrayals of Mozart's Countess or Beethoven's Leonora, the heroism of Brunnhilde or Norma, the delicious "feminine" sensibility of Schubert or Debussy. But the question remains: if a critique of gender (or race or class) were admitted into musicology, could it be successfully contained - i.e., restricted to the affirmative enterprises just mentioned?

The most obvious matter to be addressed in a feminist critique of music is the construction of gender in texted or dramatic repertories, for at least it is 
clear in these contexts that gender is an issue. From the beginnings of seventeenth-century opera, composers have been called upon to write music to put into the mouths of both male and female characters; and under those conditions, a musical semiotics of gender emerged very rapidly. Not surprisingly, characteristics of the "feminine" and the "masculine" in music are informed by beliefs deeply held by various societies about gender difference. And inasmuch as such larger-than-life images contribute to the shaping of gender in the general public - either because they transmit or because they contest traditional behavioral codes - they become highly significant. Needless to say, virtually all of such constructions have been produced by male artists.

In certain instances, it is possible to deal with the construction of female characters in opera in ways that justify the upholding of these pieces as what is brightest and best about elite culture. The Countess in The Marriage of Figaro, for instance, is more ethical, more intelligent than any of the male characters that surround her, and it is not only through the libretto that we know this. The music Mozart gives her is extraordinarily strong and dignified: in "Porgi amor," even though the accompaniment she is given is heavily ornamented and coy (in keeping with contemporary constructions of femininity in music), she sings a melodic line that is decisive and willful. She may be encased in white wig and cascades of lace, but she is a woman of great resolve. Her scena "Dove sono" reveals her to be tender and at the same time dynamic: her concluding allegro is the most dynamic music in the opera as she moves forward, overcoming all obstacles, and finally envisions her goal of reconciliation with the Count.

If all female characters in opera were like the Countess, then feminist criticism would pose no threat to the canon. Unfortunately, they are not. The very tools that permit the unpacking of the Countess's musical portrait begin to present problems when applied to many other operas. To stay with Mozart: Don Giovanni, Cosi Fan Tutte, and Die Zauberflöte all contain musical depictions that are difficult to defend - even hurtful to listen to once questions of social organization are focused on them.

In Die Zauberflöte, for instance, the young prince Tamino and his much beloved Pamina are instructed in the ways of Enlightenment and are finally shown to be worthy of admission into its inner circle. But the boundaries of this inner circle are firmly marked by figures who are excluded. First and foremost among these are the Queen of the Night - a powerful woman whose sensual, dazzling musical discourse initially seduces Tamino into accepting her mission. Later, of course, he must be trained to prefer the austere, rational utterances of the patriarchal Zarastro over her preEnlightenment "histrionics." She finally reveals herself to be a "harpy," unleashing showers of rage at her reconditioned daughter. 
By contrast, Pamina is received into patriarchal circles, but only because she learns to keep silent, not to ask questions. Her training process is extremely painful. Tamino is being taught how to be a man - that is, how to hold rigorously (Kohlberg-style) to objective law regardless of personal interests - and has been instructed not to speak to Pamina under any circumstances. Pamina, of course, is not privy to the rules of the game, and when Tamino apparently spurns her, she becomes so despondent that she contemplates suicide. In her lament, "Ach, ich fuhls," she sings that only in death will she find peace. Mozart's aria works on the mechanism of the withheld cadence that spells both closure and death: he teases us along by making us desire both that inevitable conclusion (her death) and also its deferral (the continuing spectacle of her suffering). She is passive and dutiful; she is a patriarchal plaything.

In Zauberflöte, it is not only gender that is carefully organized and packaged. The figure of Monostatos, for instance, presents an especially horrible caricature of the racial other, and the childlike birdman Papageno represents the happy-go-lucky peasant class. Significantly, the taint of sexuality is not only connected to the Queen of the Night, but it plays a major role in demonstrating why black and working-class individuals are not suitable candidates for Enlightenment: both are preoccupied with the lower, bestial aspects of human existence - with the body - as opposed to the ideals of mind and rationality that mark the road to bourgeois transcendence. In the cases of Monostatos and Papageno, their sexual appetites both bar them from upward mobility and also justify why the paternalistic ruling class must treat them like children. In the case of the Queen of the Night, the threat is so severe that she must be purged for the sake of social order. Her more obedient daughter is rewarded for her dutiful behavior, and everyone lives happily ever after.

As a feminist critic who regularly undertakes such examinations of standard opera, I have sometimes been enjoined to temper my passion with compassion. Now, I do not regard myself in general as someone lacking in compassion; but there may indeed be a problem in where my sympathies lie - which is not only with the feminine, but also with the racial or ethnic other and with the working class. Why is it that Mozart and the elite canon suddenly require compassion? When did they become the victims? Frankly, I have too much compassion for the women, black, and Jewish students in my classes to present such pieces as unquestioned masterpieces whose aesthetic worth excuses their viciousness - or to transmit unquestioningly their agendas.

Such constructions of gender, class, and race occur throughout the history of opera. For instance, the formal strictures of late seventeenth-century operatic 
reform both cleansed the operatic stage of underclass characters and imposed extraordinary formal constraints on the presentation of the feminine. If female characters of the Eighteenth Century by and large operated in accordance with the restrictive codes of Enlightenment, nineteenth-century opera released a full range of victims, madwomen, and viragos, as well as gypsies and inscrutable, blood-thirsty Chinese princesses, all of whom demand to be purged or domesticated for the sake of social order. In fact, such a reading of standard opera has already been accomplished by Catherine Clément (1988).

That such an obvious area for feminist analysis has gone untouched for the most part, however, is indicative of a much larger set of problems. To address the area of gender construction in song or opera is still to remain oddly marginalized in elite music circles: even if arguments concerning the depiction of women were granted (which they typically are not), the fact that the area of opera is itself marginalized within music means that any critique along those lines could be quarantined. To the extent that texted music is regarded as inferior, already corrupt, even "feminine," then music itself the hard-core instrumental music that counts, with its attendant theoretical formalisms - appears to remain untouched by such analyses.

Alas, the insights gained from the readings of operatic characterizations are not so readily contained. A far more significant dimension of a feminist criticism of music would involve laying bare the ways in which the social organization of gender informs even the presumably value-free aspects of instrumental music and its theories.

In fact, some of these are not difficult to recover, for it is only in the last few years of "feminist awareness" that traditional classifications based on ostensibly masculine and feminine traits have been deemed embarrassing and thus suppressed. Eighteenth-century music theorists, for instance, found these categories extremely handy: writers as far removed from each other as Georg Andreas Sorge in Germany and William Billings in colonial America judged major keys to be masculine (because of their natural strength) and minor keys to be feminine (because of their frailty, their dependence, their subordination to major).

The use of the terms of gender difference with respect to phrase endings (i.e., a tendency to call cadences that close decisively on the strong beat masculine and those that end on a so-called weak beat feminine) also persists, often with a distinct sense of moral propriety attached. Theorist Edward Cone, for instance, spends several pages addressing the "problem" of feminine cadences. He concludes:

Even in the case of movements that seem to remain incorrigibly feminine, some 
differentiation can still be made. In the case of Chopin's Polonaise in A major, for example, a clever emphasis on one of the concealed cross-rhythms at the cadence can make the last chord sound, if not precisely masculine, at least like a strong tonic postponed by a suspension of the entire dominant. (Cone 1968: 45, my italics)

What is at stake here? Why is Chopin's cadence so anxiety-provoking that Cone advocates resorting to subterfuge in order to "set it straight"? The explicit codification of sonata themes as masculine and feminine occurred only in the early years of the Nineteenth Century, yet the semiotics of gender as it had developed in opera permit us to read that basic tension in movements at least as far back as Stamitz. It is not simply the taxonomy of theme-types that is of concern here, but also the consequences of the sonataallegro narrative schema that requires (as though by natural law) that the masculine theme's key finally prevail over the key of the feminine theme in order to ensure closure. (Interestingly, Mozart, Schubert, and others wrote movements in which patriarchal force is resisted, while conventionally feminine themes are valorized. Gender-sensitive criticism need not be damaging to the canon as a whole.)

What we learn from examining the construction of the "masculine" in instrumental music is often more than we really want to admit. Musik in Geschichte und Gegenwart characterizes masculine themes as "thrusting" and aggressive, and effective readings of Beethoven symphonies or Strauss tone poems are guaranteed to have male audience members pumping their fists in the lobby as they describe how the performance had "balls." In other words, much of this music is concerned with the celebration of the phallus - which would be alright if this were openly acknowledged, as it is, for instance, in rock. But what blocks criticism is the sanctimonious pretense that classical instrumental music transcends such mundane matters: one is required over and over again to worship at the phallic shrine but is not permitted to call it by name.

In suggesting that we revive this heavily gendered terminology of the past, I am not advocating that we return to the time when such concepts were applied indiscriminately, unproblematically. I remember the discomfort I felt as an undergraduate being taught (along Cone's lines) that the presumably defective moments in music were feminine: even my music theory classes served to teach me my place, to reinforce my sense of fundamental inadequacy. I certainly do not want to go back to those bad old days. But today, when musicologists and theorists have chosen to pretend that none of this gendered marking ever occurred or that Cone's statement is simply an aberration, one is prevented from critiquing what has been in fact a pervasive mode of organizing music and, by extension, gender.

The conventional Western binary opposition of masculinity/femininity 
informs countless other dimensions of music and its institutions. Literary critic Jochen Schulte-Sasse (1986-7) has investigated the tension between reason and imagination in late eighteenth-century aesthetics documents and has demonstrated that reason was regarded as masculine, artistic imagination feminine and thus potentially dangerous, uncontainable. The fact that the early Romantics self-consciously embraced feminine imagination in opposition to masculine reason, subjectivity in opposition to objectivity, indicates that much more of musical productivity is marked by socially constructed concepts of gender difference than simple thematic types. The tensions between closure-oriented norms and subversive deviations in nineteenth-century musical discourse throw into confusion fundamental lines of gender identity and patriarchal allegiance. The defensive masculine posturing of the nineteenth-century male artist who was colonizing what was regarded as a feminine terrain is therefore not surprising - nor is the insistence that actual women not be permitted to participate.

But most of this is now concealed by a pervasive institutional reluctance to address musical content at all. Most people care about music because it resonates with experiences that otherwise go unarticulated, whether it is the flood of cathartic release that occurs at the climax of a Tchaikowsky symphony or the groove that causes one's body to dance - that is, to experience itself in a new way. Yet our music theories and notational systems do everything possible to mask those dimensions of music that are related to physical human experience and focus instead on the orderly, the rational, the cerebral. The fact that the majority of listeners engage with music for more immediate purposes is frowned upon by our institutions.

The reasons for this disapproval are often hidden in the ideology of idealism, in that rigid set of interlocking Western binary oppositions (i.e., culture/nature, mind/body, objectivity/subjectivity, European/racial or colonial other, bourgeois/working class, etc.) that collapse back onto masculine/feminine. To let slip the dominant term of any one of those oppositions is apparently to lose them all - is no longer to be a man. Nowhere is the lethal interdependence of these pairs more evident than at the end of Carmen, where with one stroke of the knife, Don José purges the threats of the feminine, of the chromatic, of desire and the body, of the underclass, of the non-white, of the non-Christian, of popular culture. Occasionally, the mapping of gender onto issues of race and class comes to the surface even in theory. Witness Adorno's hysterical reactions to the rhythmic dimension of jazz: to enjoy the beat in jazz, to permit its irrational African pulse to direct the body in dance is to submit masochistically to castration - that is, to have given up that natural sign not only of sexual, but also of racial, class, and intellectual dominance. Only by holding on to masculine reason can the feminine threats of the non-white and of the body be held at bay. Klaus Theweleit (1988) demonstrates how thoroughly intermeshed these oppositions were in the 
writings of the National Socialists - how what was at stake in the purge of the Holocaust was at once racial, class, and sexual anxiety.

Unfortunately, these interlocked oppositions continue to inform a good deal of what does and does not get talked about in music. Benjamin Boretz's (1972) attempt at reading the Tristan prelude as pitch-class sets rather than as metaphors expressive of longing likewise hinge on this horror of desire - ultimately, the horror of femininity - and a need to exert mastery over it. The strange absence of even humanistic criticism in music is linked to the urge to appropriate and control by reason those phenomena that intrigue precisely because they tend to resist such control.

A feminist criticism of any music, then, would have to be concerned with uncovering the dimensions of Western music that are organized according to all of those pervasive and pernicious metaphysical dichotomies. We cannot afford to focus solely on obvious instances of gender - to be one-issue critics - but we must also be alert to the politics of race, of class, of subjectivity, of popular culture: those elements that traditionally have been relegated to the "feminine" slagheap. Indeed, recent attacks on criticism by William Bennett (1984) and Allan Bloom (1987) make it very clear how much elite culture regards all these threats as interchangeable.

Feminist criticism would also focus on those dimensions of music that involve desire and that engage the body. By "the body," I do not mean some kind of transhistorical entity. Our experiences of our bodies and sexualities are as socially constructed as any other dimension of culture. It is in part because music plays such a prominent role in that fundamental shaping that it needs to be taken so seriously. Once again, this is not as difficult a task as it might initially seem: people have to be taught not to respond to music physically, rather than the reverse. However, to admit into academic discourse accounts of physical motion, desire, and models of sexuality (heterosexual and homosexual, male and female) is perhaps to perform the greatest transgression of all: to use the tools of analysis to acknowledge and validate the construction of those images most profoundly threatening to its conventional authority.

The purposes of such deconstructive readings of music are several. To the very large extent that music is informed by issues directly or indirectly bound up with gender and sexuality, the investigation of how compositions and repertories articulate gender difference and the erotic contributes enormously to our understanding of music as a social discourse: as a medium in which the fears and hopes of a people are played out, negotiated, and shared, a medium which is both shaped by social values and in turn contributes to the organization of conduct and beliefs. This would seem to be a far richer way of dealing with music than those that insist on order and 
style codification - even though it would foreground much of the darker side of the discourse.

But feminist criticism of music has more practical ramifications than the intellectual interpretation of the past. Because music has been dealt with in ways that make its procedures (which are almost invariably male constructs) appear to be value-free, we have inadequate methods for understanding the small amount of music produced by women. I have often heard historians of women composers end their biographical talks by apologizing for the "slightness" of the music itself. Often such low assessments are the result of the historian's having resorted uncritically to "objective" male standards.

But many women musicians seem to me to be trying to do different things within the musical discourses they inherited - to make some kind of imprint, to register some sign of difference against conventional codes. Barbara Strozzi's seventeenth-century secular cantatas, for instance, often involve the invocation of normal discursive practices (such that one can hear her considerable abilities within these idioms) and then deliberate rupture. She thus creates an ironic distance from the norms, a refusal to follow the usual strategy of blurring experiential and musical realities through the carefully plotted manipulation of desire: what was called at the time "moving the passions." She makes the seams of her own constructions highly apparent; she may even be heard as performing a kind of deconstruction that would implicate as well the compositions of her competitors. Likewise, the songs of Clara Schumann might be heard not as less authoritative than those of Robert (which almost always include little thrusting eddies of excitement), but as articulating a more reassuring, nurturing, constant mode of expression.

For women writing and performing music today, the impact of feminist critical methods is invaluable. Simply being able to identify where gender difference has been located in music (past and present) facilitates the development of other modes of composing. I do not believe in essentialism, and thus do not think that women compose differently automatically by sheer virtue of being female. But it seems to me desirable that at least occasionally women negotiate within their inherited discourses differently - that they have the information with which to make choices and to explore alternative strategies.

Many women composers today are concerned to demonstrate that they can write music indistinguishable from that of their male colleagues. This is not surprising, given the long history of women being told that they are incapable of doing so and also given the tendency for male critics to sniff around to locate some moment of "feminine" inadequacy in whatever a woman composer writes. 
But some are beginning to create music that insists on difference, often taking the terms set in traditional discourses but playing them out in ways that call traditional premises into question. Meredith Monk, for instance, utilizes the vocal sounds and rhythms of children's games (the stuff of the domestic sphere to which women have so long been bound) as the raw materials for new structures. Diamanda Galas invokes the sounds of women traditionally regarded as taboo - the shrieks and guttural moans of the madwoman, the keening of Greek mourners in her protests against political oppression and the abuse of AIDS victims. One has only to compare this music with the domesticated versions of the madwoman in, say, Lucia di Lamermoor, or the Queen of the Night, to hear how artificial, how carefully sanitized those operatic spectacles are and how powerful it is when a woman artist takes possession of those sounds for her own uses. In the popular realm Madonna is engaged with similar strategies of seizing the signs of patriarchal constructions of femininity for her own purposes.

To return once more to the question posed at the beginning, "How is the work of art to survive the social critique?," it is very possible that it cannot do so unscathed, that we will have to begin taking responsibility for what gets transmitted in art. The same person who asked me this question added: "The whole problem has arisen because ... there is no viable contemporary repertoire. There is no alternative to Mozart for us. In former days art reflected its time. In our day the art we treasure reflects the past and its values. That's the central problem.'

Clearly, I do not agree. I think there is plenty of music by women, by black or Chicano musicians, by people of the working and rural classes, that not only avoids the kinds of difficulties I have been pointing to, but that is also extremely effective music. The pernicious mind/body split that so informs classical music is simply not operative in much of this music, which manages to be both politically astute and physically engaging. There are, of course, exceptions - popular music that is every bit as worrisome as Puccini - but there are also many public forums in which the political and musical merits of new artists, albums, and movements are openly debated. At the same time, the elite avant-garde continues uncritically to celebrate Morton Subotnick's new technologically advanced ways of enacting the beast's rape of the blind, handless but grateful female. Give me Laurie Anderson, Prince, or Madonna any day. 


\section{REFERENCES}

BENNETT, WILLIAM.

1984: Reclaiming a Legacy. Washington: National Endowment for the Humanities.

BLOOM, ALLAN.

1987: The Closing of the American Mind. New York: Simon and Schuster.

BORETZ, BENJAMIN.

1972: “Meta-Variations, Part of: Analytic Fallout (I)," Perspectives of New Music, 11: 159-217.

CLEMENT, CATHERINE.

1988: Opera, or the Undoing of Women. Minneapolis: University of Minnesota Press.

CONE, EDWARD T.

1968: Musical Form and Musical Performance. New York: W.W. Norton.

SCHULTE-SASSE, JOCHEN.

1986-7: "Imagination and Modernity: or the Taming of the Human Mind," Cultural Critique, 5: 23-48.

THEWELEIT, KLAUS.

1988: Male Fantasies. Minneapolis: University of Minnesota Press. 